\title{
SISTEM PAKAR DIAGNOSA KERUSAKAN PRINTER MENGGUNAKAN METODE CERTAINTY FACTOR
}

\author{
${ }^{1}$ Jajang Nurjaman, ${ }^{2}$ Kusrini. \\ UNIVERSITAS AMIKOM YOGYAKARTA \\ e-mail: ${ }^{1}$ za2ng2509@gmail.com, ${ }^{2}$ kusrini@amikom.ac.id
}

\begin{abstract}
ABSTRAK
Berkembangnya penggunaan komputer saat ini dirasa sangat pesat dan sangat bermanfaat untuk kelangsungan hidup manusia. Banyak pekerjaan manusia yang dapat diselesaikan oleh komputer, sehingga komputer menjadi bagian yang tidak dapat dipisahkan dari kehidupan sehari-hari.
\end{abstract}

Kerusakan hardware Komputer diantaranya pada printer merupakan masalah yang sering terjadi sehingga memerlukan analisa yang akurat dalam melakukan perbaikan, tentu saja tanpa pemahaman dan ilmu pengetahuan maka seseorang tidak akan dapat mengetahui secara pasti pada kerusakan tersebut, sehingga membutuhkan suatu aplikasi sistem pakar untuk melakukan perbaikan, yang akan dilakukan.pada penelitian ini untuk mengukur tingkat akurasi aplikasi sistem pakar menggunakan metode certainty factor untuk mendiagnosa kerusakan pada printer.

Dari hasil penelitian didapatkan bahwa metode certainty factor dapat bekerja dengan baik pada aplikasi sistem pakar untuk mendiagnosa kerusakan printer dibuktikan dengan melakukan pengujian pada beberapa kerusakan dan mendapatkan hasil yang sama pada proses perhitungan secara manual.

Kata Kunci :Sistem, Pakar, Printer, Certainty Factor.

\section{PENDAHULUAN}

Berkembangnya penggunaan komputer saat ini dirasa sangat pesat dan sangat bermanfaat untuk kelangsungan hidup manusia. Banyak pekerjaan manusia yang dapat diselesaikan oleh komputer, sehingga komputer menjadi bagian yang tidak dapat dipisahkan dari kehidupan sehari-hari. Kerusakan hardware pada printer merupakan masalah yang sering terjadi, berbagai macam kerusakan sering muncul bisa diakibatkan oleh faktor penggunaan atau pun juga karena masa pemakaian printer yang sudah terlalu lama sehingga mengakibatkan bermacam - macam kerusakan. Sementara itu seorang teknisi pemula terkadang kesulitan ketika mendeteksi kerusakan printer secara cepat karena kerusakan tersebut memerlukan diagnosa dan harus melakukan pembongkaran telebih dahulu sehingga memperlambat dalam memberikan informasi kerusakan kepada para pelanggannya.

Masalah ini menjadi alasan tersendiri bagi penulis untuk dapat membuat sebuah perangkat lunak yang mampu mendeteksi kerusakan pada hardwareprinter dan 
juga mampu untuk membantu para teknisi pemula dalam melakukan perbaikan kerusakan pada printer, perangkat lunak tersebut seringkali disebut sebagai sistem pakar. Sistem pakar ini termasuk salah satu bagian dari kecerdasan buatan.Sistem pakar adalah suatu program komputer yang dirancang untuk mengambil keputusan seperti keputusan yang diambil oleh seorang atau beberapa orang pakar. Atau dapat diatikan juga sebagai sistem perangkat lunak komputer yang menggunakan ilmu, fakta, dan teknik berpikir dalam pengambilan keputusan untuk menyelesaikan masalah-masalah yang biasanya hanya dapat diselesaikan oleh tenaga ahli dalam bidang yang bersangkutan.

Dari pernyataan tersebut, penulis mencoba untuk mengimplementasikan pikiran-pikiran pakar pada sebuah perangkat lunak. Perangkat lunak tersebut akan mampu mendeteksi kerusakan yang terjadi pada printer dan juga akan memberikan solusi kepada kepada seorang teknisi.Berawal dari sulitnya mencari informasi mengenai cara perbaikan serta perawatan pada printer tersebut makapenulis tertarik untuk membuat software yang dapat membantu memecahkan permasalahan kerusakan pada printer.

\section{KAJIAN PUSTAKA}

Besarnya manfaat aplikasi sistem pakar sehingga dipergunakan di banyak bidang karena sangat berguna bagi dalam menggantikan peran pakar. Penelitian sistem pakar telah banyak dilakukan oleh para peneliti saat ini dengan metode metode yang bervariasi pada berbagai bidang. namun penelitian reparasi khususnya dalam diagnosa kerusakan printer secara khusus masih jarang dilakukan. Kajian pustakan dilakukan pada beberapa jurnal dan buku. Adapun kajian yang dilakukan pada beberapa jurnal dianaranya adalah :

1. Penelitian yang lain yang telah dilakukan dalam penelitian aplikasi sistem pakar diantarnya adalah Penerapan Metode Certainty Factor Dalam Perancangan Sistem Pakar Pendiagnosa Kerusakan Laptop (Yanto,Hendri,Ifbro,2016) dari penelitian yang telah dilakukan dapat mengatasi factor kepastian kerusakan pada laptop.

2. Penelitian lain juga dilakukan untuk diagnosa dini defisiensi vitamin dan Mineral (Labellapansa, Boyz,2016), Metode penelusuran defisiensi menggunakan forward chaining sedangkan untuk menangani ketidakpastian yang muncul digunakan metode certainty factor. Untuk memudahkan pengguna, maka sistem dibuat dengan menggunakan teknologi mobile. Berdasarkan pengujian yang dilakukan kepada pakar dapat dibuktikan bahwa sistem pakar yang dibangun mampu mendiagnosa defisiensi vitamin dan mineral dengan nilai akurasi kebenaran sebesar $100 \%$. Dengan diketahuinya defisiensi yang terjadi maka penanganan dan pencegahan dapat dilakukan secara lebih dini. oleh Ause Label lapansa Fakultas Teknik Univeristas Islam Riau hasil dari penelitian tersebut didapatkan bahwa sistem yang dikembangkan dapat membantu mengatasi factor ketidakpastian diagnose defisiensi vitamin dan mineral pada tubuh manusia.

3. Penelitian lain dalam bidang penyakit tanaman untuk mengidentifikasi Penyakit pada tanaman semangka (Harto,2013) hasil yang didapatkan diketahui bahwa metode certainty factor cocok untuk mengatasi ketidakpastian menentukan 
dalam penyakit tanaman semangka. Berdasarkan dari penelitian diatas membukatikan bahwa metode certainty factor dapat dipergunakan diberbagai bidang walaupun pada awalnya penelitian yang dilakukan oleh tim MYCIN sistem pakar hanya untuk digunakan untuk mengatasi ketidakpastian dalam bidang kesehatan .

Selain mengambil acuan pada jurnal dilakukan jukan kajian terhadap beberapap sumber mengenai metode yang diteliti, dari kajian beberapa sumber mengenai materi yang diteliti adalah sebagai berikut :

\section{Sistem pakar}

Menurut Profesor Edward Feigebaum dari universitas Stanford yang merupakan seorang pelopor awal dari teknologi system pakar medefinisikan bahwa "Suatu program Komputer cerdas yang menggunakan knowledge (pengetahuan) dan prosedur inferensi untuk menyelesaikan masalah yang cukup sulit sehingga membutuhkan seorang ahli untuk menyelesaikan nya."

(Feignbaum:1982). Suatu sistem pakar adalah suatu system computer yang menyamai kemampuan pengambilan keputusan dari seorang pakar.(Arhani:2005) Ciri-ciri sistem pakar menurut Turban adalah sebagai berikut:

a. Terbatas pada domain keahlian tertentu.

b. Dapat memberikan penalaran untuk data data yang tidak pasti.

c. Dapat mengemukan rangkaian alasan-alasan yang diberikannya dengan cara yang dapat dipahami.

d. Berdasarkan pada kaidah tertentu.

e. Dirancang untuk dapat dikembangkan secara bertahap.

f. Keluaranya bersifat anjuran.

\section{Certainty Factor}

Menurut Kusrini (2008:15). Faktor Kepastian (Certainty Factor) diperkenalkan oleh Shortliffe Buchanan dalam pembuatan MYCIN (Wesley, 1984). Certainty Factor (CF) merupakan nilai parameter klinis yang diberikan MYCIN untuk menunjukkan besarnya kepercayaan.

Dalam Certainty theory, data - data kualitatif direpresintakan sebagai derajat keyakinan (degree of belief), ada dua langkah untuk mempresentasikan data - data kualitatif, langkah pertama adalah kemampuan untuk mengekpresikan derajat keyakinan, langkah kedua adalah kemampuan untuk menempatkan dan mengkombinasikan derajat keyakinan tersebut dalam sistem pakar.

Dalam mengekpresikan derajat keyakinan certainty theory menggunakan suatu nilai yang disebut dengan certainty factor untuk mengasumsikan seorang pakar terhadap suatu data (Arhami : 2005). certainty factor memperkenalkan konsep belief/keyakinan dan disbelief/ketidakyakinan. Konsep ini kemudian diformulasikan dalam rumusan dasar sebagai berikut :

$$
\mathrm{CF}(\mathrm{H}, \mathrm{E})=\mathrm{MB}(\mathrm{H}, \mathrm{E})-\mathrm{MD}(\mathrm{H}-\mathrm{E})
$$


1. $\mathrm{CF}(\mathrm{H}, \mathrm{E})$, Certainty Factor dari hipotesis $\mathrm{H}$ yang dipengaruhi oleh gejala /fakta (evidence) E. Besarnya CF berkisar antara -1 sampai 1. Nilai 1 menunjukkan ketidakpercayaan mutlak, sedangkan nilai 1 menunjukkan kepercayaan mutlak.

2. $\mathrm{MB}(\mathrm{H}, \mathrm{E})$, ukuran kenaikan kepercayaan (measure of increased belief) terhadap hipotesis $\mathrm{H}$ yang dipengaruhi oleh gejala $\mathrm{E}$.

3. $\mathrm{MD}(\mathrm{H}, \mathrm{H})$ : ukuran kenaikan ketidakpercayaan (measure of increased disbelief) terhadap hipotesis $\mathrm{H}$ yang dipengaruhi oleh gejala $\mathrm{E}$.

a. Menentukan CF Paralel

CF Paralel merupakan $\mathrm{CF}$ yang diperoleh dari beberaoa premis pada sebuah aturan. Besarnya CF Sequensial dipengaruhi oleh CF User untuk masing - masing premis dan operator dari premis. Berikut adalah rumus masing-masing operator :

1. $\mathrm{CF}(\mathrm{x}$ dan $\mathrm{y})=\operatorname{Min}(\mathrm{CF}(\mathrm{x}), \mathrm{CF}(\mathrm{y}))$

2. $\mathrm{CF}(\mathrm{x}$ atau $\mathrm{y})=\operatorname{Max}(\mathrm{CF}(\mathrm{x}), \mathrm{CF}(\mathrm{y}))$

b. Menentukan CF Sequensial

Bentuk dasar rumus Certainty Factor sebuah aturan JIKA E MAKA H dituliskan dengan rumus sebagai berikut :

$$
\mathrm{CF}(\mathrm{H}, \mathrm{e})=\mathrm{CF}(\mathrm{E}, \mathrm{e}) * \mathrm{CF}(\mathrm{H}, \mathrm{E})
$$

Keterangan :

$\mathrm{CF}(\mathrm{E}, \mathrm{e})=$ Certainty Factor evidence $\mathrm{E}$ yang dipengaruhi evidence $\mathrm{e}$

$\mathrm{CF}(\mathrm{H}, \mathrm{E})=$ Certainty Factor hipotesis dengan asusmsi evidence diketahui dengan pasti, yaitu $\mathrm{CF}(\mathrm{E}, \mathrm{e})=1$

$\mathrm{CF}(\mathrm{H}, \mathrm{e})=$ Certainty Factor hipotesis yang dipengaruhi evidence e

$\mathrm{CF}$ sequensial diperoleh dari perhitungan $\mathrm{CF}$ Paralel dari semua premis dalam satu aturan yang diberikan oleh $\mathrm{CF}$ Pakar, maka rumusnya adalah sebagai berikut :

$$
\mathrm{CF}(\mathrm{x}, \mathrm{y})=\mathrm{CF}(\mathrm{x}) * \mathrm{CF}(\mathrm{y})
$$

Keterangan :

$\mathrm{CF}(\mathrm{x}, \mathrm{y})=\mathrm{CF}$ Paralel

$\mathrm{CF}(\mathrm{x})=\mathrm{CF}$ Sequensial

$\mathrm{CF}(\mathrm{y})=\mathrm{CF}$ Pakar

\section{Hasil dan Pembahasan}

Untuk mendiagnosa suatu Kerusakan perlu diketahui terlebih dahulu gejalagejala yang ditimbulkan. Meskipun hanya dari gejala klinis (gejala-gejala yang terlihat langsung), Pakar dapat mengambil suatu kesimpulan berupa kerusakan apa yang terjadi. Berikut adalah data yang digunakan pada penelitian ini :

Tabel 1 Gejala Kerusakan 


\begin{tabular}{|c|l|}
\hline $\begin{array}{c}\text { Kode } \\
\text { Gejala }\end{array}$ & \\
\hline G01 & Hasil cetakannya ada beberapa garis tidak teratur \\
\hline G02 & Warna terlihat bercampur \\
\hline G03 & HeadCatridge terlihat cacat \\
\hline G04 & Catridge tidak terdeteksi \\
\hline G05 & Ketika dinyalakan terlihat normal \\
\hline G06 & $\begin{array}{l}\text { ketika dipakai untuk melakukan print terdengar bunyi keras seperti gear } \\
\text { yang kesangkut sesuatu }\end{array}$ \\
\hline G07 & Tidak dapat menarik kertas \\
\hline G08 & Ketika di hidupkan, printer tidak jalan sama sekali \\
\hline G09 & Lampu led kedap kedip \\
\hline G10 & Printer tidak berfungsi sama sekali \\
\hline G11 & Hasil Cetakan Terputus-putus, Buram dan Bergaris \\
\hline G12 & Hasil print ngeblok \\
\hline G13 & Tidak Ada Tinta Yang Keluar \\
\hline G14 & Tinta Macet \\
\hline G15 & Muncul peringatan General Error \\
\hline G16 & Tidak dapat melakukan print resume catridge \\
\hline G17 & Printer tidak berfungsi \\
\hline G18 & muncul status printer pada monitor “ink catriges cannot be recognized" \\
\hline
\end{tabular}

Tabel 2 Kerusakan

\begin{tabular}{|c|c|lc|}
\hline No & $\begin{array}{c}\text { Kode } \\
\text { Kerusakan }\end{array}$ & & \\
\hline 1 & K01 & Catridge Rusak & \\
\hline
\end{tabular}




\begin{tabular}{|c|c|l|}
\hline 2 & K02 & ASF printer Epson( bunyi keras pada printer Epson) \\
\hline 3 & K03 & Printer Epson (service required) \\
\hline 4 & K04 & Kerusakan Head \\
\hline 5 & K05 & Kerusakan chip catridge \\
\hline
\end{tabular}

Tabel 3 Aturan CF Pakar

\begin{tabular}{|c|c|c|c|c|c|c|c|c|c|c|c|c|c|c|c|c|c|c|c|c|}
\hline \multirow[b]{2}{*}{ No } & \multicolumn{18}{|c|}{ Kode Gejala } & \multirow[b]{2}{*}{$\begin{array}{c}\text { Kode } \\
\text { Kerusakan }\end{array}$} & \multirow{2}{*}{$\mathrm{CF}$} \\
\hline & $\begin{array}{c}\text { G0 } \\
1\end{array}$ & $\begin{array}{c}\text { G0 } \\
2\end{array}$ & $\begin{array}{c}\mathrm{G} \\
03 \\
\end{array}$ & $\begin{array}{c}\mathrm{G} \\
04 \\
\end{array}$ & $\begin{array}{c}\mathrm{G} \\
05 \\
\end{array}$ & $\begin{array}{c}\mathrm{G} \\
06\end{array}$ & $\begin{array}{c}G \\
07 \\
\end{array}$ & $\begin{array}{c}\mathrm{G} \\
08 \\
\end{array}$ & $\begin{array}{c}\mathrm{G} \\
09 \\
\end{array}$ & $\begin{array}{c}\mathrm{G} \\
10\end{array}$ & $\begin{array}{c}\mathrm{G} \\
11 \\
\end{array}$ & $\begin{array}{c}\mathrm{G} \\
12 \\
\end{array}$ & $\begin{array}{c}G \\
13 \\
\end{array}$ & $\begin{array}{c}\mathrm{G} \\
14 \\
\end{array}$ & $\begin{array}{c}\mathrm{G} \\
15 \\
\end{array}$ & $\begin{array}{c}G \\
16 \\
\end{array}$ & $\begin{array}{c}G \\
17 \\
\end{array}$ & $\begin{array}{c}\mathrm{G} \\
18 \\
\end{array}$ & & \\
\hline 1 & $\mathrm{x}$ & $\mathrm{x}$ & & & & & & & & & & & & & & & & & K01 & 0,8 \\
\hline 2 & & & $\mathrm{x}$ & $\mathrm{x}$ & & & & & & & & & & & & & & & K01 & 0,8 \\
\hline 3 & $\mathrm{x}$ & $\mathrm{x}$ & & $\mathrm{x}$ & & & & & & & & & & & & & & & K01 & 0,9 \\
\hline 4 & & $\mathrm{x}$ & $\mathrm{x}$ & $\mathrm{x}$ & & & & & & & & & & & & & & & K01 & 0,5 \\
\hline 5 & $\mathrm{x}$ & $\mathrm{x}$ & $\mathrm{x}$ & $\mathrm{x}$ & & & & & & & & & & & & & & & K01 & 1 \\
\hline 6 & & & & & $x$ & $\mathrm{x}$ & $\mathrm{x}$ & & & & & & & & & & & & K02 & 1 \\
\hline 7 & & & & & $\mathrm{x}$ & & $\mathrm{x}$ & & & & & & & & & & & & K02 & 0,8 \\
\hline 8 & & & & & & & & $\mathrm{x}$ & $\mathrm{x}$ & & & & & & & & & & K03 & 1 \\
\hline 9 & & & & & & & & & & $\mathrm{x}$ & $\mathrm{x}$ & & & & & & & & K04 & 0,8 \\
\hline 10 & & & & & & & & & & & & $\mathrm{x}$ & $x$ & & & & & & K04 & 0,5 \\
\hline 11 & & & & & & & & & & $\mathrm{x}$ & $\mathrm{x}$ & & $\mathrm{x}$ & & & & & & K04 & 0,8 \\
\hline 12 & & & & & & & & & & $\mathrm{x}$ & $\mathrm{x}$ & $\mathrm{x}$ & $\mathrm{x}$ & & & & & & K04 & 1 \\
\hline 13 & & & & & & & & & & & & & & $\mathrm{x}$ & $\mathrm{x}$ & & & & K05 & 0,5 \\
\hline 14 & & & & & & & & & & & & & & & $\mathrm{x}$ & $\mathrm{x}$ & & & K05 & 0,5 \\
\hline 15 & & & & & & & & & & & & & & $\mathrm{x}$ & $\mathrm{x}$ & $x$ & & & K05 & 0,8 \\
\hline 16 & & & & & & & & & & & & & & & $\mathrm{x}$ & $\mathrm{x}$ & $\mathrm{x}$ & $\mathrm{x}$ & K05 & 0,8 \\
\hline 17 & & & & & & & & & & & & & & $\mathrm{x}$ & $\mathrm{x}$ & $\mathrm{x}$ & $\mathrm{x}$ & & K05 & 0,8 \\
\hline 18 & & & & & & & & & & & & & & $\mathrm{x}$ & $\mathrm{x}$ & $\mathrm{x}$ & $\mathrm{x}$ & $\mathrm{x}$ & K05 & 1 \\
\hline
\end{tabular}




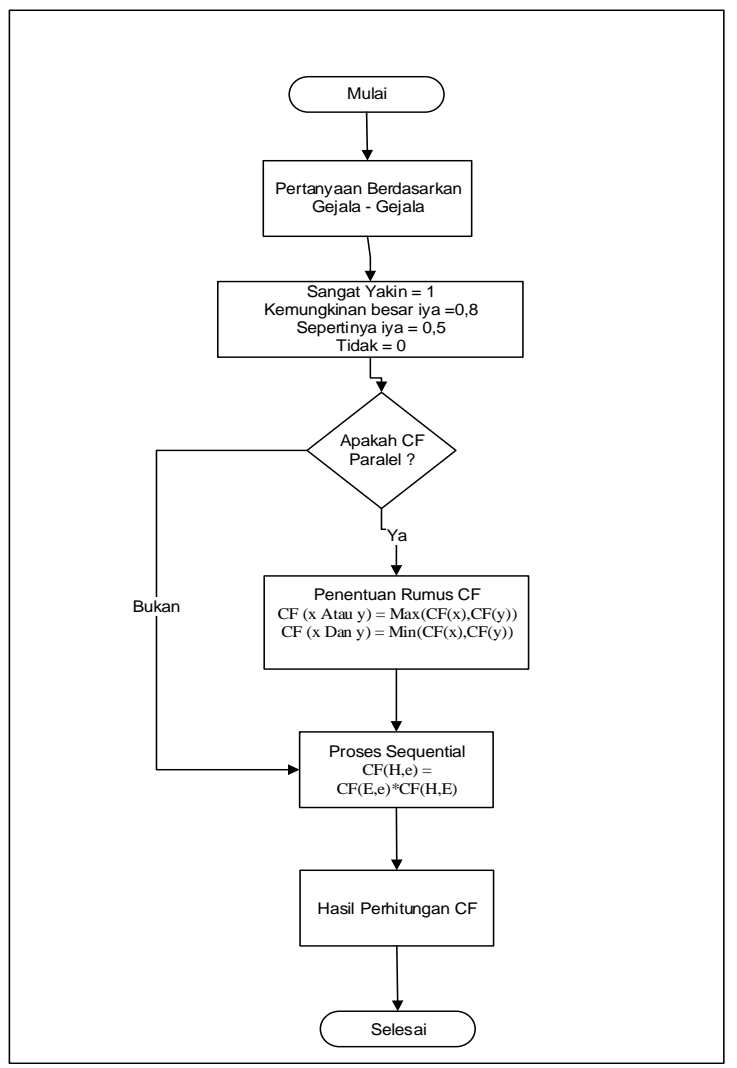

Gambar 1. Flowchartperhitungan certainty factor

Gambar diatas merupakan alur perhitungan certainty factor adapun langkah langkah nya sebagai berikut :

1. Tentukan pertanyaan - pertanyaan berdasarkan gejala yang telah ditentukan oleh seorang pakar.

2. Fakta gejala yang dipilih oleh user diberikan bobot.

3. Penentuan $\mathrm{CF}$ paralel atau sequential, apabila $\mathrm{CF}$ paralel maka perhitungan akan menggunakan CF parallel yaitu dengan menggunakan persamaan (3) apabila sequential maka akan dihtung menggunakan persamaan (4)

4. Hasil diagnosa berupa nilai CF dan berupa saran - saran

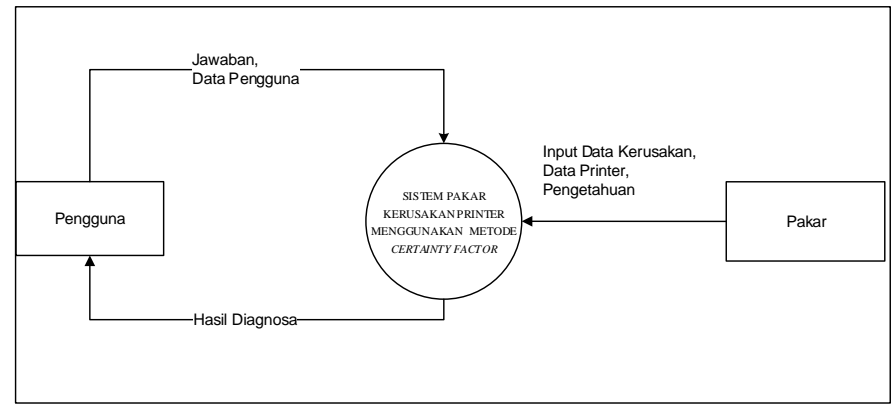

Gambar 2. Diagram Konteks

Gambar 2 merupakan diagram konteks dari sistem yang akan dibangun dimana sistem ini memiliki dua entitas yaitu pakar dan pengguna. 


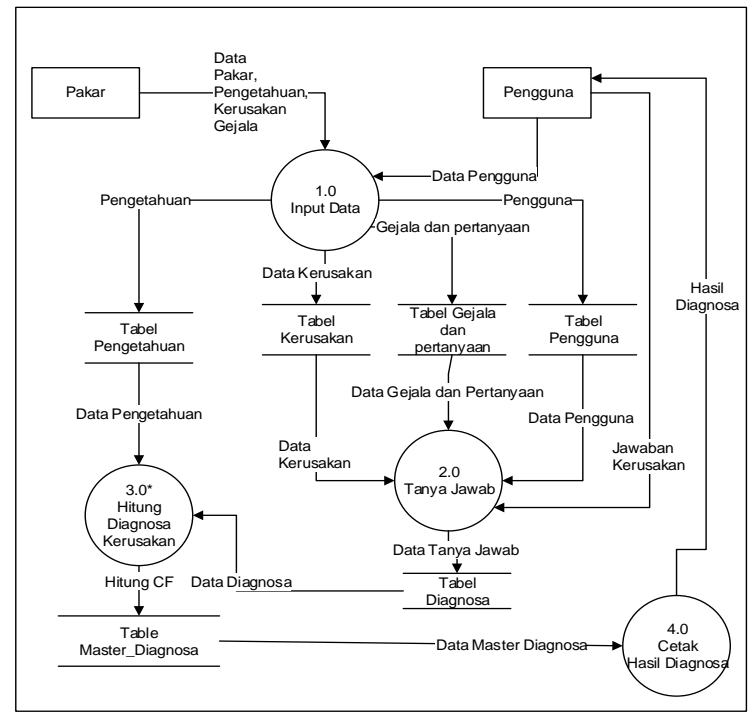

Gambar 3. Data Flow Diagram

Setelah membuat diagram konteks, maka tahapan rancangan selanjutnya adalah membuat Data Flow Diagram (DFD) seperti gambar 3. Pada DFD diatas dapat dilihat bahwa sistem ini mempunyai 4 proses yang nantinya akan dibuat ke dalam sistem

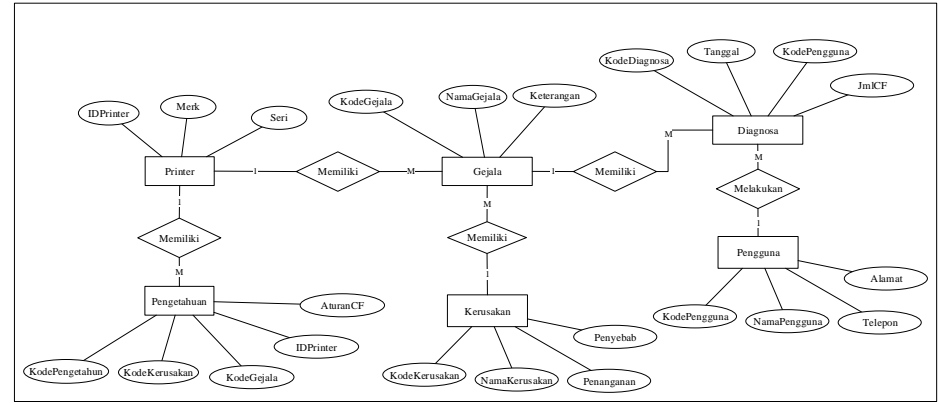

Gambar 4. Entity Relationship Diagram

Untuk melakukan perancangan database, dibuatlah sebuah ERD seperti yang seperti pada gambar 4. Setelah itu maka ERD tersebut ditransformasikan ke dalam bentuk table. Adapun hasil dari pembuatan sistem dapat dilihat pada gambar di berikut ini :

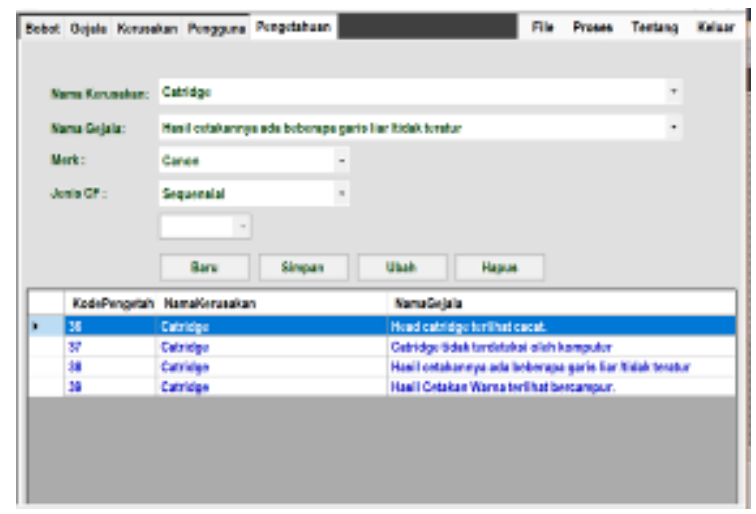




\section{Gambar 5. Input Data Pengetahuan}

Sistem yang dibangun terdiri dari dua hak akses yaitu Admin dan Pengguna gambar diatas merupakan form untuk akses admin yang terdiri dari beberapa input diantaranya adalah input data bobot,gejala,kerusakan,kelola pengguna dan input data pengetahuan.

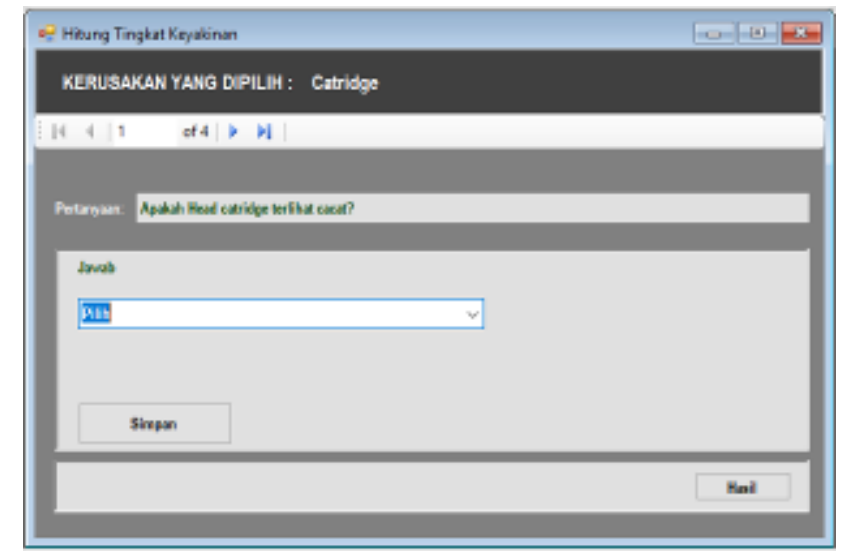

Gambar 6. Input Data Tingkat Keyakinan

Gambar diatas adalah hak akses pengguna, digunakan untuk input data keyakinan yang dilakukan oleh pengguna, berupa dialog pertanyaan berdasarkan gejala - gejala yang ada kemudian jawaban berupa tingkat keyakinan yang diinput berupa :

Tabel 4 Tingkat Keyakinan

\begin{tabular}{|c|l|c|}
\hline Kode & & Nilai \\
\hline Y1 & Sangat yakin & 1 \\
\hline Y2 & Yakin & 0.8 \\
\hline Y3 & Kemungkinan iya & 0.5 \\
\hline Y4 & Kemungkinan tidak & 0.4 \\
\hline Y5 & Tidak & 0 \\
\hline
\end{tabular}


Contoh kasus berdasarkan data diatas pada kerusakan Catridge pada adapun gejala kerusakan sebagai berikut :

1. Hasil cetakannya ada beberapa garis liar (tidak teratur).

2. Warna terlihat bercampur.

3. Head Catridge terlihat cacat.

4. Catridge tidak terdeteksi.

Langkah selanjutnya, pakar menentukan nilai CF untuk masing-masing fakta dan gejala kerusakan, masing - masing gejala diberikan bobot berupa persentase, besar persen ditentukan sendiri oleh pakar berdasarkan analisa terhadap suatu kerusakan dan berdasarkan pengalaman pakar sendiri. Suatu contoh untuk penentuan nilai CF pada kerusakan Catridge sebagai berikut :

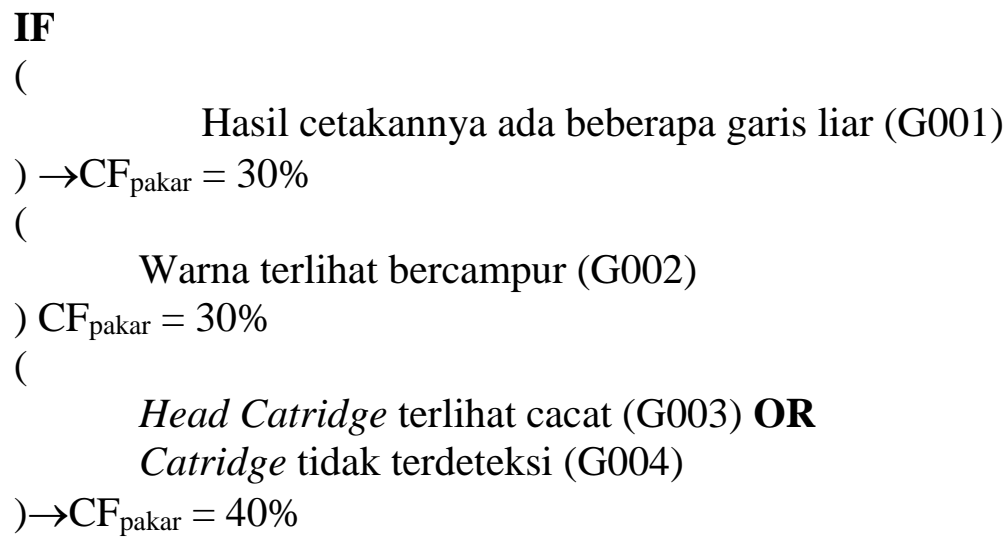

THEN Catridge Rusak $\rightarrow \mathrm{CF}_{\text {pakar }}$ total $=100 \%$

Persamaan (6) diatas merupakan contoh aturan untuk mendiagnosa kerusakan catridge, besar nilai aturan didapatkan dari pakar yang telah mempunyai pengalaman dalam penanganan tersebut. Tiap - tiap gejala diberikan nilai oleh pakar kemudian dari gejala tersebut ditentukan gejala apa saja yang termasuk $\mathrm{CF}$ sequensial dan parallel sehingga total CF yang diberikan pakar sebanyak 100\%,

Dengan menulis kode dari fakta dan gejala saja maka certainty factor hipotesis pada saat evidence pasti adalah : 100\% Misalkan User memilih jawaban sebagai berikut :

Tabel 5 CF Userr

\begin{tabular}{|c|c|l|l|c|}
\hline No & Kode Gejala & Nama Gejala & Jawaban & Bobot \\
\hline 1 & G001 & $\begin{array}{l}\text { Hasil } \\
\text { cetakannya } \\
\text { ada beberapa } \\
\text { garis liar } \\
\text { (tidak } \\
\text { teratur). }\end{array}$ & Sangat Yakin & 1 \\
\hline
\end{tabular}




\begin{tabular}{|c|c|l|l|c|}
\hline 2 & G002 & $\begin{array}{l}\text { Warna } \\
\text { terlihat } \\
\text { bercampur. }\end{array}$ & Sepertinya Iya & 0,5 \\
\hline 3 & G003 & $\begin{array}{l}\text { Head } \\
\text { Catridge } \\
\text { terlihat cacat. }\end{array}$ & Sepertinya Iya & 0,5 \\
\hline 4 & G004 & $\begin{array}{l}\text { Catridge tidak } \\
\text { terdeteksi. }\end{array}$ & Kemungkinan Besar Iya & 0,8 \\
\hline
\end{tabular}

Langkah berikutnya adalah menghitung CF sequential. Yang harus dicari CF paralelnya terlebih dahulu tetapi untuk yang lainnya sudah langsung dapat di hitung $\mathrm{CF}$ sequential nya. Pada contoh studi kasus diatas terdiri dari CFparalel yaitu :

1. Head catridge terlihat cacat $(\mathrm{G} 003)=0.5$

2. Catridge tidak terdeteksi (G004) $=0.8$

CFparalel nya adalah MAX[0.6,0.8] $=0.8$

Sehingga :

CFsequential $=0.8 * 0,4=0,32$

CFsequential $=1 * 0,3=0,3$

CFsequential $=0.5 * 0,3=0,15$

Jadi CF total untuk untuk diagnosa kerusakan Catridge adalah sebagai berikut :

CFtotal $=0,32+0,3+0,15=0,77$.

Hasil perbandingan dari aturan yang diberikan oleh pakar yaitu 1 dan Perhitungan $\mathrm{CF}$ sequensial tersebut menghasilkan presentase keyakinan sebesar 0.77 Hal tersbut membuktikan bahwa implementasi metode certainty factor pada sistem tersebut telah dilakukan dengan benar dikarenakan hasil dari perhitungan $\mathrm{CF}$ tidak akan lebih besar dari aturan yang diberikan oleh pakar.

\section{Kesimpulan}

Kesimpulan yang dapat di ambil dari berdasarkan penelitian yang dilakukan adalah sebagai berikut :

1. Metode certainty factor dapat digunakan untuk mengatasi factor kepastian pada kerusakan printer dibuktikan denga melakukan proses perhitungan secara manual dan aplikasi yang sudah dibangun.

2. Penerapan metode certainty factor pada kerusakan printer dilakukan dengan mencari gejala-gejala yang berhubungan dengan suatu kerusakan dan 
memberikan bobot terhadap gejala-gejala yang ditemukan, kemudian cocokan dengan pengetahuan pakar.

\section{Daftar Pustaka}

Arhami Muhammad, 2005, Konsep Dasar Sistem Pakar,Andi, Yogyakarta

Kusrini. 2006, Sistem Pakar Teori dan Aplikasi, CV. Andi Offset, Yogyakarta.

Priyanto, Rahmat, Langsung Bisa Visual Basic.Net 2008, 2009 C.V. Andi Offset, Yogyakarta.

Simarmata, Janner, Rekayasa Perangkat Lunak, 2009 C.V. Andi Offset, Yogyakarta.

Kusrini. M.Kom., Strategi Perancangan dan Pengelolaan Basis Data, 2007, C.V. Andi Offset, Yogyakarta.

Andi offset, Pengembangan Sistem Pakar Menggunakan Visual Basic, 2009 C.V.Andi Offset Yogyakarta.

Nugroho, Adi, Rekayasa Perangkat Lunak Berorientasi Objek dengan Metode USDP, hal. 4, 2010, C.V. Andi Offset, Yogyakarta.

Keken Wilujeung, Yessy Yanitasari, Supriyadi, Abdul Gowi4, Sistem Pakar Gangguan Ansietas Perpisahan Masa Kanak dan Remaja menggunakan Certainty Factor Berbasis web, ILKOM Jurnal Ilmiah Volume 9 Nomor 1 April 2017, ISSN Print 2087-1716,ISSN online 2548-7779,2017

Nur Anjas Sari, Sistem pakar mendiagnosa penyakit demam Berdarah menggunakan metode Certainty Factor, Pelita Informatika Budi Darma, Volume : IV, Nomor: 3, Agustus 2013 ISSN : 2301-9425

https://id.wikipedia.org/wiki/Kecerdasan_buatan, Diakses pada tanggal 10 Juli 2017. 